\title{
Selling Sex in World Cities, 16oos-20oos: An Introduction
}

\author{
Magaly Rodríguez García, Elise van Nederveen Meerkerk and \\ Lex Heerma van Voss
}

Christian Grey's biological mother was Ella, a drug-addicted sex worker. Christian and Ella lived in extreme poverty in Detroit and both were badly abused by Ella's pimp. Christian was 4 years old when his mother committed suicide; he spent four days with her dead body until the pimp found them and called the police. In later life, Christian only referred to his mother as "the crack whore".

The background of one of the main characters of the best seller Fifty Shades trilogy is characterized by platitudes that are all too often believed to be "typical" of prostitution: poverty, male abuse, economic exploitation, drugs, decadence, and trauma. Yet the extent to which these representations of prostitution are supported by sound empirical evidence has since the last decades of the twentieth century increasingly been questioned by scholars, activists, and sex workers who call for the integration of commercial sex in the realm of labour. This book seeks to engage in this ongoing debate by means of a global and comparative history of female prostitution in cities worldwide from 1600 to the present.

Notwithstanding the large number of national studies on particular aspects of prostitution (policies, attitudes, and labour market), no international comparison over a significant span of time has ever been attempted. We start in the early modern period in order to gauge whether practices and attitudes regarding prostitution have altered throughout the last four centuries around the world. By including the precolonial situation, we aim to observe to what extent prostitution changed with the settlement of Europeans in overseas territories. Although the distinction between "premodern" and "modern" prostitution is perhaps not very sharp, we presume that the important political, military, and socioeconomic changes that took place from ca. 1600 onward have had a profound impact on the sale of sex. The long historical and broad geographical approach of our project permits us to draw some general conclusions regarding the extent to which the practice of prostitution and societal reactions to it have been influenced by processes of colonization, industrialization, urbanization, the rise of nation-states, nationalism, and war, as well as revolutions in the 
realms of politics, transport, and communication. Furthermore, the increased organization of prostitutes in the twentieth and twenty-first centuries, as well as the increased scholarly attention that has been paid to prostitution and the main actors in the sex industry (prostitutes, pimps, brothel keepers, traffickers, and clients), have encouraged us to extend the research to the present. The focus on female prostitution in urban settings is justified on the one hand because commercial sex has nearly always been an urban phenomenon involving women servicing men, and on the other hand because the information available is limited, as male and transgender prostitution in the past, as well as rural prostitution, have been even more elusive than female sex work.

The project follows the research model used in earlier comparative projects carried out by the International Institute of Social History (Amsterdam, the Netherlands) on the history of dock and textile workers. ${ }^{1}$ In the first phase of the project we solicited a set of urban studies on the history of prostitution in different countries for the period between 1600 and the present. To facilitate international comparisons, the authors of these urban overviews were requested to systematically address a number of topics/questions that were listed in a framework document. The latter is included below as an appendix to this introduction. In the second phase of the project, we invited a number of authors to write thematic comparative essays based on the collection of urban overviews. In the third stage of the project, the authors of the urban and thematic papers, as well as other experts on prostitution (in total nearly forty researchers from around the world) came together at the conference "Selling Sex in the City: Prostitution in World Cities, 1600 to the Present", which took place at the International Institute of Social History from 25 to 27 April 2013. This volume contains the revised versions of a selection of the papers presented at that conference. More information about the book's structure and the regions and themes contained therein will be provided at the end of this introductory note. Priority is given first to a justification of the choices we have made for this collective research project.

Even though the participants in the project were not explicitly required to adopt a particular approach to prostitution, we requested that they focus not only on the policies, societal attitudes, and structural factors that have influenced the sex industry but also on prostitutes' profiles and culture, as well as on working and living conditions. We-and many of the authors involved in this

1 These projects resulted in the publication of two edited volumes: Sam Davies et al. (eds), Dock Workers: International Explorations in Comparative Labour History, 1790-1970 (Aldershot, 200o) and Lex Heerma van Voss, Els Hiemstra-Kuperus, and Elise van Nederveen Meerkerk (eds), Ashgate Companion to the History of Textile Workers, 1650-200o (Farnham, 2010). 
and other scientific studies - understand prostitution to be a form of work and therefore attempt to achieve a comprehensive overview of this activity from a global labour history perspective. This approach is linked to our understanding of work, which goes beyond the exclusionary concepts of labour that became dominant from the nineteenth century onward. For instance, writing in the 183os, French nobleman Adolphe Granier de Cassagnac divided the proletariat into four groups, "the workers, the beggars, the thieves and the public women", implying an understanding of only the first category to be "real" workers. In his view, "the worker is a proletarian, because he works in order to live and earns a wage; the beggar is a proletarian, who does not want to work or cannot work, and begs in order to live; the thief is a proletarian, who does not want to work or beg, and, in order to make a living, steals; the prostitute is a proletarian, who neither wants to work, nor beg, nor steal, and, in order to live, sells her body." ${ }^{2}$ Around the same period, the Communist League articulated the desire of "respectable" and "free" workers (meaning male wage earners) to distinguish themselves from slaves and other unfree labourers, the self-employed and the lumpenproletariat. And although Karl Marx himself seems to have been rather ambiguous about prostitutes and their relation vis-à-vis the working class, ${ }^{3}$ most nineteenth-century commentators defined survival activities such as prostitution as unproductive, work-shy, deviant, or even criminal. ${ }^{4}$

This narrow conceptualization of work, which led to the institutionalization and idealization of wage labour, has increasingly been challenged. Already at the end of the 180os, new terms were introduced to describe activities that take place outside or at the edge of the conventional labour market. The political scientist Rotering, for example, referred to activities that are perceived as a public nuisance and that are distinct from "decent" or "formal" work as

2 Adolphe Granier de Cassagnac, Histoire des classes ouvrières et des classes bourgeoises (Paris, 1838), p. 30. See also Jan Lucassen, "Writing Global Labour History c. 1800-1940: A Historiography of Concepts, Periods and Geographical Scope", in idem (ed.), Global Labour History: A State of the Art (Bern, 2008), pp. 39-90, 51.

3 As Marcel van der Linden, Workers of the World: Essays towards a Global Labour History (Leiden, 2008), p. 22, footnote 15 argues, "When [Marx] discusses the relative surplus population in Capital, he regards prostitutes as an important part of the 'actual lumpenproletariat' (Capital, I, p. 797). Elsewhere, especially in the Theories of Surplus Value, I, pp. 166 and 186, Marx says that prostitutes, if they work for a brothel keeper, perform (unproductive) wage labor, like actors or musicians, and thus are, by implication, part of the proletariat in the narrow sense of the word."

4 Sebastian Conrad, et al., "Die Kodifizierung der Arbeit: Individum, Gesellschaft, Nation", in Jürgen Kocka and Claus Offe (eds), Geschichte und Zukunft der Arbeit (Frankfurt [etc.], 1999), pp. 449-475; van der Linden, Workers of the World, pp. 10, 266-268. 
"negative work". ${ }^{5}$ But the expansion of the concept of work has only recently become popular among scholars and activists. Over the last decades, terms such as "precarious labour" and "informal" and "irregular work" have been used to depict (respectively) poorly paid, short-term, and unstable occupations, jobs excluded from the formal economy, and income-generating activities to which "a heterodox or even asocial character is attributed inasmuch as they lack general approval."6 These novel conceptualizations have enabled the inclusion of reproductive or "female activities" such as care work and domestic service within the world of labour. ${ }^{7}$

The labour approach to prostitution follows this recent shift in the social sciences. In particular, historians have been of crucial importance in the removal of prostitution from the literature of crime and deviancy and the inclusion of prostitutes in the history of work. ${ }^{8}$ Yet, to paraphrase Timothy Gilfoyle, new academic interpretations of prostitution hardly undermine traditional views on commercial sex. ${ }^{9}$ Broadly speaking, we can identify four trends (which are not necessarily mutually exclusive) within societal analyses and the scientific study of prostitution. ${ }^{10}$ The deviant framework-much in vogue in

"Die negative Arbeit", Von Landesgerichtsdirektor Rotering zu Beuthen (Oberschlesien), Zeitschrift für die gesamte Strafrechtswissenschaft, 16 (1896), pp. 198-223, 198, quoted in Sigrid Wadauer, "Work, Non-Work and Negative Work", paper presented at the XIV International Economic History Conference, Helsinki, 2006, p. 2, available at: www.helsinki.fi/ iehc20o6/papers2/Wadauer.pdf; last accessed 7 July 2017.

Thomas Buchner and Philip R. Hoffmann-Rehnitz, "Introduction: Irregular Economic Practices as a Topic of Modern (Urban) History_Problems and Possibilities", in idem (eds), Shadow Economics and Irregular Work in Urban Europe: $16^{\text {th }}$ to Early $20^{\text {th }}$ Centuries (Vienna, 2011), pp. 3-36, 18; Sudhir Alladi Venkatesh, Off the Books. The Underground Economy of the Urban Poor (Cambridge, 2006).

7 See for example, Dirk Hoerder, Elise van Nederveen Meerkerk, and Silke Neunsinger (eds), Towards a Global History of Domestic and Caregiving Workers (Leiden, 2015).

8 Timothy Gilfoyle, "Prostitutes in History: From Parables of Pornography to Metaphors of Modernity", The American Historical Review, 104 (1999), pp. 117-141, 120. According to Judith Walkowitz, there seems to be a consensus among American and British historians who treat prostitutes as "workers and agents in history" and who interpret prostitution as a form of labour, not necessarily "noble or dignified labor, but labor nonetheless." Judith Walkowitz, "History and the Politics of Prostitution: Prostitution and the Politics of History", keynote address delivered at the second meeting of the Cost Action "Comparing European Prostitution Policies: Understanding Scales and Cultures of Governance", Salamanca, 11 September 2014.

9 Gilfoyle, "Prostitutes in History", p. 120.

10 Joyce Outshoorn, "Introduction: Prostitution, Women's Movements and Democratic Politics", in idem (ed.), The Politics of Prostitution. Women's Movements, Democratic States and the Globalisation of Sex Commerce (Cambridge, 2004), pp. 1-20, 6-9. Since the list of works 
the modern period but certainly not defunct in the twentieth and twenty-first centuries-departs from the assumption that prostitution creates a law and order problem because it gives rise to all kinds of uncivilized, asocial, criminal, and unhealthy behaviour. Scholars, social workers, activists, and public authorities who support this view define prostitution in terms of deviant behaviour that needs to be controlled, regulated, or prohibited. ${ }^{11}$ In the morality view, prostitution is perceived as a sin and a social evil or as symbolic of the double sexual standard for men and women. ${ }^{12}$ Somewhat linked to the former, the oppression model holds that prostitution comes about through gender inequality and poverty. Its proponents insist that disadvantaged socioeconomic circumstances and gendered power relations force women into prostitution. Their "appalling" condition thus exposes them to exploitative situations as well as violence and human trafficking. Within this approach, the "prostituted woman" is not criminalized but victimized. Since these women are not seen as persons who exchange sexual services for money or other benefits but as victims who are compelled to sell their bodies in patriarchal societies, prostitution is often defined as rape or sexual slavery. ${ }^{13}$ The sex work paradigm also departs from a socioeconomic and gender analysis but contrary to the oppression view, it stresses the agency of the people involved in prostitution. It focuses on the opinions and motivations of the concerned actors who implicitly or explicitly perceive prostitution as an alternative way to make a living, often preferable to other strenuous, dangerous, and low-paid jobs.

on prostitution that represent these trends is enormous, we will only cite here a few examples of each of them.

11 Cesare Lombroso and Guglielmo Ferrero, La donna delinquente, la prostituta et la donna normale (Torino, 1893); this work has been translated in its totality by Hahn Rafter and Mary Gibson: Criminal Woman, the Prostitute and the Normal Woman (Durham, 2004). See also, Sybil Neville Rolfe, "Biological Aspects of Prostitution", in idem, A Social Problem Group (London, 1937); Hilary L. Surratt et al., "Sex Work and Drug Use in a Subculture of Violence", Crime \& Delinquency, 50 (2004), pp. 43-59.

12 William Acton, Prostitution, Considered in its Moral, Social and Sanitary Aspects, in London and other Large Cities. With Proposals for the Mitigations and Prevention of its Attendant Evils (London, 1857); Prevention of Prostitution. A Study of Measures Adopted or Under Consideration Particularly with Regard to Minors (Geneva, 1943).

13 Kathleen Barry, Female Sexual Slavery (Englewood Cliffs, 1979); Carole Pateman, "Defending Prostitution: Charges against Ericsson”, Ethics, 93 (1983), pp. 561-565, 562; Ashwini Tambe, Codes of Misconduct. Regulating Prostitution in Late Colonial Bombay (Minneapolis, 2009); Sheila Jeffreys, The Idea of Prostitution (North Melbourne, 1997); idem, The Industrial Vagina: The Political Economy of the Global Sex Trade (London [etc.], 2009). How men and transgender persons involved in commercial sex fit within this analytical framework is unclear. 
The labour approach to prostitution has been influenced by various intertwined forces, the first of which is the increasing participation of women in public protests. Even though the beginning of the sex workers' movement is commonly located in the 1970s, evidence exists of prostitutes organizing protests and stating their demands to the authorities already by the end of the nineteenth century. In British territories, Indian prostitutes protested against the harsh regulation system; in imperial Russia, they demanded health examinations of clients, not just prostitutes; in New Orleans in 1907, prostitutes organized a successful strike against rent increases; and in the 1930s, Argentinian women involved in prostitution used printed media to call for better working conditions and respect for prostitutes as workers. In interwar Germany, prostitutes developed various strategies to resist abuse and gain more control over their working conditions; some even formed their own union, the Association of the Legal Prostitutes of Hamburg and Altona. In the United States too, early trade unions like the Industrial Workers of the World approached prostitution as work and had prostitutes as members. ${ }^{14}$ Then, as the political and cultural changes brought about by the 1960s and '7os led to a further strengthening of the feminist movement, prostitutes in different parts of the world became more vocal and appropriated the language of human rights to create more stable structures. The introduction of the terms "sex work" and "sex worker" has been an important semantic shift signifying the growth of a movement that understands commercial sex in terms of labour and expects state protection. ${ }^{15}$

Obviously, stretching the concept of labour to include societal phenomena such as prostitution within the legal parameters of work can have political and socioeconomic consequences that (with a few exceptions) not even secular, highly sexualized societies seem prepared to cope with. On a theoretical level, this conceptual expansion can also have implications for the social sciences. As Yvonne Svanström questions, "How far can the work-concept be stretched

14 Eileen Boris and Heather Berg, "Protecting Virtue, Erasing Labor: Historical Responses to Trafficking”, in Kimberley Kay Hoang and Rhacel Salazar Parreñas (eds), Human Trafficking Reconsidered. Rethinking the Problem, Envisioning New Solutions (New York, 2014), pp. 19-29, 21; Gregor Gall, An Agency of their Own: Sex Worker Union Organizing (Winchester, 2012), p. 13; Donna J. Guy, Sex and Danger in Buenos Aires: Prostitution, Family and Nation in Argentina (Lincoln, 1991), p. 200; Victoria Harris, Selling Sex in the Reich: Prostitutes in German Society, 1914-1945 (Oxford, 2010), pp. 61-64.

15 Jo Bindman, "Redefining Prostitution as Sex Work on the International Agenda" (AntiSlavery International, 1997), available at: http://www.walnet.org/csis/papers/redefining .html\#text1; last accessed 7 July 2017. 
without losing its meaning?"16 Should all remunerated activities, including begging, petty crime, surrogate pregnancy, and so on, as well as unpaid occupations such as elder and child care, housekeeping, subsistence farming or volunteer work be treated as work irrespective of how the people involved or society at large perceive these tasks?

John Budd offers a broad conceptualization which makes it possible to understand all such activities as work: "work is defined [...] as purposeful human activity involving physical or mental exertion that is not undertaken solely for pleasure and that has economic or symbolic value."17 True, the boundaries between work and non-work/leisure are often blurred, especially when entertainment, sexuality, and emotions are involved. But if we understand work to be the "production of useful objects or services", 18 then prostitution is a form of labour. There is no reason why overtly or less overtly sexualized activities such as acting, modelling, professional dancing, massaging, and so on should be viewed as work/service and prostitution should not. The working and living conditions of prostitutes are often substandard and degrading but as the contributions to this book evidence, this situation seems to come about due to a lack of state protection, outright repression, and stigma rather than from an intrinsically harmful nature associated with prostitution. Moreover, detrimental physical and psychological effects can occur in all kinds of occupations. As Kimberly-Anne Ford has demonstrated in her comparative study of hospital work and prostitution in Montreal, the stress levels and assault rates among orderlies and prostitutes were surprisingly similar. ${ }^{19}$

Hence if we treat prostitution as the provision of sexual services, shouldn't we, once and for all, get rid of the old terms and systematically use "sex work" and "sex worker" instead? We choose not to, and use both "sex work/er" and "prostitution/prostitute" nearly interchangeably throughout this book. Even though some authors have a preference for one over the other, sex work (in the narrow sense) is used here as a synonym for prostitution. This brings us to

16 Comments on the papers of the session "Selling Sex in the City 1600-200o: Comparison", European Social Science History Conference, Vienna, 23 April 2014.

17 John W. Budd, The Thought of Work (Ithaca, 2011), pp. 2-3.

18 Marcel van der Linden, "Studying Attitudes to Work Worldwide, 1500-1650: Concepts, Sources, and Problems of Interpretation", International Review of Social History, 56 (2011), pp. $25-43,27$.

19 Kimberly-Anne Ford, "Evaluating Prostitution as a Human Service Occupation", in James E. Elias et al. (eds), On Whores, Hustlers, and Johns (Amherst, NY, 1998), cited in Lena Edlund and Evelyn Korn, “A Theory of Prostitution”, Journal of Political Economy, 110 (2002), pp. 181-214, 188-189. 
another intricate issue: a justification for the terms used and the definition of prostitution.

At the start of the project that led to this publication we did not offer the participants a definition of prostitution, but we asked them to pay attention to the overlapping of legal and cultural conceptualizations throughout place and time. In other words, we asked them to make clear what in the city or town discussed a prostitute was considered to be, and what kind of activities constituted prostitution and which ones did not. As the authors of this book demonstrate, the variety of sexual arrangements or "loose behaviours" that public authorities and private actors have perceived to be outright or close to prostitution is immense. We prefer the simplest possible definition. A barebones definition of prostitution would be that it is the provision of physical sex for payment and this is done with no prospects for marriage. The latter is included to distinguish prostitution from long-term socially accepted relationships that involve sexual exchange and financial arrangements. ${ }^{20}$ Payment is intentionally imprecise so that it can include other forms of remuneration besides money, and to leave the distinction between "treating"21 and payment to the cultural norms of the time and place in question. That the sex should be physical is included to distinguish prostitution from paid sexually-charged services like stripping, phone sex, or pornography. All these forms of commercial sex are included in the (broadly understood) term "sex work".

Recently, other notions have been introduced to describe situations in which an upfront monetary transaction does not take place, like sex-tourism relations and sexual-economic relationships with teenagers or young men and

20 Edlund and Korn, "A Theory of Prostitution", pp. 181-214, 183-184, from which we borrow the basic elements of our definition, also claim that sex in prostitution is, from the man's/client's point of view, non-reproductive. This is useful in their analysis, where they compare marriage with the selling of reproductive sex, with prostitution as the selling of non-reproductive sex. For the long-term and global approach taken up in this project, this distinction seems too narrow. It assumes, for instance, that effective contraceptive measures and/or knowledge about them were/are always available, and unnecessarily excludes the practice of short-term marriages from prostitution, or forms of prostitution that mimic marriage.

21 The custom of "treating" became popular at the end of the nineteenth and beginning of the twentieth centuries in New York. It referred to the trade of sexual favours for theatre tickets, drinks, and other small presents by working-class women or "charity girls", as they were known in underworld slang. Kathy Peiss, Cheap Amusements: Working Women and Leisure in Turn of the Century New York (Philadelphia, 1986); Elizabeth Alice Clement, Love for Sale: Courting, Treating and Prostitution in New York City, 1900-1954 (Chapel Hill, 2006). 
women, where gifts such as trips, meals, phones, drugs, or school tuition are seen as being compensation for the services rendered. According to Kamala Kempadoo, the notion "transactional sex" is more useful in describing the activities of persons who are located outside the sex industry. Transactional sex can be read as "the umbrella term for all acts, including but not limited to sex work, where sexuality is exchanged for material and other non-sexual benefits." ${ }^{22}$ Similarly, Amalia Cabezas challenges the concept of sex work as the only viable tool for understanding interactions between tourists and locals in Cuba and the Dominican Republic. She argues that important issues such as affection, companionship, and intimacy are absent in the terms "prostitution" and "sex work". For this reason, Cabezas chooses to use the term "tactical sex", which serves as a better means of understanding the "complex circulation of sex and affect". The importance of gifts is emphasized, as they represent an "important feature of exchange and solidarity" and can transform the sexual relationship into one of courtship and love. ${ }^{23}$

Neologisms like sex work, transactional sex, or tactical sex stress the selfperception of the actors concerned and avoid the stigma surrounding prostitution. As with "charity girls", ${ }^{24}$ people involved in transactional or tactical sex do not define themselves as "prostitutes" or "sex workers" but rather as "escorts", "entertainers", "business girls", "beach boys", "friends", and so on; and, people engaged in the unambiguous exchange of sex for money today tend to prefer the term "sex worker". ${ }^{25}$ Yet the new terminology has its limitations. As Kamala Kempadoo admits, "the notion of tactical sex closely approximates what has been described $[\ldots]$ as transactional sex, even while the definitions of both

22 Kamala Kempadoo, Prostitution, Sex Work and Transactional Sex in the English-, Dutchand French-Speaking Caribbean: A Literature Review of Definitions, Laws and Research (Greater Georgetown, 2009), p. 14.

23 Amalia Cabezas, Economies of Desire: Sex and Tourism in Cuba and the Dominican Republic (Philadelphia, 2009), pp. 120, 122.

24 See footnote 21.

25 Not all persons involved in prostitution like the term "sex worker". Some perceive it as being a politically-correct word that does nothing to de-stigmatize prostitution. Others seem to dislike it because it would transform prostitution into an ordinary occupation; in their view, it is the taboo that makes it appealing and profitable. However, most of them acknowledge the political strength of the term, which can help to improve their working and living conditions. Melissa Hope Ditmore, "Introduction", in idem (ed.), Encyclopedia of Prostitution and Sex Work (Westport, 2006), pp. xxv-xxxvii. These points were also made during a study-day on prostitution organized by the city of Antwerp, Belgium (June 2014), to which public authorities, social workers, prostitutes, and academics (including Magaly Rodríguez García) were invited to participate. 
remain fuzzy."26 Furthermore, the boundary between transactional/tactical sex and prostitution/sex work is not always clear.

According to Amalia Cabezas, the term "tactical sex" makes it possible for us to acknowledge that commodification and affection are not mutually exclusive, but this can also be said of unequivocal sex work. Sufficient empirical evidence exists which testifies that prostitutes in past and present societies have often offered much more than fast and unceremonious sexual intercourse, and that their relations with loyal clients frequently involved friendship and even affection. ${ }^{27}$ Transactional sex is said to respond to the interest of new needs (the "commodities of modernity"), rather than basic ones. ${ }^{28}$ However, past and contemporary prostitutes have often justified their involvement in commercial sex in terms other than pure economic survival. The proponents of these new terms also aim to avoid the so-called essentialism of words like prostitution and sex work. They correctly point out that these activities (particularly when practised by women) have since ancient times been understood in terms of identity, not mere occupations. But this is not inherent in prostitution. In numerous (past and present) cultures, the link between one's/somebody else's job and identity is very strong. ${ }^{29}$

This conceptual overview demonstrates that there is no single word that encompasses the complexity of commercial sexualities. ${ }^{30}$ The new lexicon is a

26 Kempadoo, Prostitution, Sex Work and Transactional Sex, p. 15.

27 A recent study on purchasers of sex conducted at Simon Fraser University, Canada, found that male clients often value companionship as much as sex. Chris Atchison, "Report for the Preliminary Findings for John's Voice: A Study of Adult Canadian Sex Buyers", 2010, available at: http://www.johnsvoice.ca/; last accessed 7 July 2017. When the oldest prostitute from Brussels retired in 2011, she told the press her life story. During the thirty-five years she spent behind a window in the red-light district, she had had five long relationships with men who had been her clients before. Paul Demeyer, "Sonia (59) heeft haar laatste klant ontvangen", Nieuwsblad, 2 March 2011, available: at http://www.nieuwsblad. be/cnt/gvi3716p8; last accessed 7 July 2017. Stories of sex workers establishing affectionate bonds with clients abound in ego documents and Internet blogs.

28 Suzanne Leclerc-Madlala, "Transactional Sex and the Pursuit of Modernity", Social Dynamics: A Journal of African Studies, 29 (2003), pp. 213-233.

29 "Except for the sexist language that should not be seen as excluding women, noted sociologist Everett Hughes's observation from 1971 remains relevant today: 'A man's work is one of the things by which he is judged, and certainly one of the more significant things by which he judges himself." Quoted in Budd, The Thought of Work, p. 149.

30 For a long-term overview of the notions that have been used to refer to the sex trade in different times and societies, see: Magaly Rodríguez García, "Defining Commercial Sexualities, Past and Present”, in Kath Browne and Gavin Brown (eds), Routledge Research Companion to Geographies of Sex and Sexualities (Surrey, 2016), pp. 321-329. 
welcome warning against the myths, generalizations, and oversimplifications that abound whenever commercial sex is discussed. This has been achieved through the bottom-up approach of research initiatives that include the points of view of the people directly involved in these activities. Yet the danger of deconstructing the use of sexuality in the exchange of material or non-material benefits is that some "sexual-affective-economic activities"31 become romanticized as feelings or companionship are stressed at the expense of economic considerations. After all, we should keep in mind that authorities, jurists, doctors, and social workers were and are not the only ones who seek to construct commercial sexualities within the scope of single terms such as "fornication", "whoredom", or "prostitution". The actors who are involved themselves contribute to the creation of new discourses which attempt (but often fail) to draw a radical distinction between prostitution, sex work, sexual barter, and transactional or tactical sex. Indeed, as Amalia Cabezas compellingly states, "the exchange of goods and money for sexual services is not an unambiguous commercial endeavour but a discursive construction that is contested and in motion, changing across time and space."32

So for the sake of clarity, the traditional words "prostitution/prostitute" will be continued to be used here. Prostitution is more straightforward than the terms sex work, transactional sex, treating, and so on, even though all of them refer to "a sexual exchange for money or other valuables." ${ }^{33}$ It is also a concept that appears in the legislation and popular writings of most countries. Admittedly, as various authors in this book point out, "prostitution" and "prostitute" (and its foreign equivalents) became widely used only after the end of the eighteenth century to differentiate the sale of sex from simple fornication and adulterous behaviour. But their origins lay in antiquity. Both words are based on the Latin terms prostituere or prostare which referred to methods and places of solicitation: standing in front of a brothel.

Another reason why the maintenance of these terms seems to be justifiable is that they reflect the stigma that has characterized prostitution throughout most of history, or perhaps more accurately, the history of prostitutes. As Lena Edlund and Evelyn Korn state in their theory of prostitution, "while attitudes toward prostitution have vacillated between condemnation and laissez-faire, the prostitute herself has suffered a consistently poor reputation." ${ }^{34}$ Indeed, although some forms of high-level prostitution in earlier times commanded

\footnotetext{
31 Kempadoo, Prostitution, Sex Work and Transactional Sex, p. 15.

32 Cabezas, Economies of Desire, p. 4.

33 Ditmore, "Introduction", p. xxv.

34 Edlund and Korn, "A Theory of Prostitution", pp. 207-208.
} 
respect and prestige, most societies have treated prostitutes with contempt. At times, they were seen as being part of the working class but the efforts made to differentiate "good" from "bad" women seem to have been ubiquitous. From antiquity to the present, the use of distinguishable clothing or ornaments and zoning laws have served the purpose of singling out and keeping sex workers at a safe distance from "respectable" society.

The poor reputation of prostitution has deep roots. Throughout time and space the notions used to describe commercial sexualities have nearly always involved a condemnation of atypical sex acts. In spite of the geographical and time differences in the way the sex trade has been practised and policed, the available literature demonstrates that sexual desire has been deemed disruptive in most cultures. As it became increasingly commodified with the rise of industrial societies, the nation-state, and globalization, commercial sex became a constant preoccupation of elites and the bourgeoisie. Particularly women using sex for purposes other than (future) procreation were (and still are in many places) openly or less openly incriminated. ${ }^{35}$ Female promiscuity has been commonly condemned in all patriarchal societies as it threatens the ability to ascertain paternity on the part of men and, from women's point of view, to secure faithful and healthy husbands or partners. Moreover, the nexus between female licentiousness and financial or material gain exacerbates the anxiety of men in their traditional roles as family heads and breadwinners. In short, the "female capacity of opportunistic promiscuity threatens the very premise of the patriarchal family, and the prostitute is a constant reminder of this ability." 36

However, since the nineteenth century the vilification of sex workers has increasingly made room for victimization. The increasing commercialization of sexual activities in capitalist societies seems to have run parallel with an increased sense of moral opprobrium, either because it is associated with wantonness, unruly behaviour, and laziness or because it is understood to be a violation of women's dignity. Indeed, the notion of the "fallen woman" could refer to the sinful or unruly behaviour for which she is responsible, but also to situations of vulnerability in which women fall prey to malevolent men. Since the second half of the nineteenth century, women involved in prostitution

Michel Foucault, Histoire de la sexualité: La volonté de savoir (Paris, 1976); Robert Barker, Kathleen Wininger and Frederick Elliston, The Philosophy of Sex (New York, 1984); Nina Peršak and Gert Vermeulen, "Faces and Spaces of Prostitution", in idem (eds), Reframing Prostitution. From Discourse to Description, from Moralisation to Normalisation? (Antwerp, 2014), pp. 13-24.

36 Edlund and Korn, “A Theory of Prostitution", p. 208. 
have been increasingly perceived as victims in western countries where the feminist movement gained ground. In Great Britain, feminists and libertarians helped publicize a series of sexual scandals in the 1880 s which ended with the reporting on Jack the Ripper and the murder of five prostitutes. William Stead's publication of newspaper articles about the abduction of English girls who were then sold to continental brothels, in addition to the media attention given to the Ripper murders, rendered all men suspect and strengthened the notions of urban danger and female fragility. ${ }^{37}$ The link between (migration for) prostitution, male violence, economic oppression, and trafficking was established in this way; by the end of the nineteenth century, a movement for the suppression of the "white slave traffic" 38 emerged in Britain and spread internationally. Since the early twentieth century, national and international initiatives to curtail female trafficking have gone in crescendo, and the view of prostitution as a harmful activity in which women are the main victims has become increasingly influential. ${ }^{39}$

The idea of "unusual sexuality" and the perception of sex workers as threats or victims have not only reinforced the bad reputation of prostitution, but they have also made it more difficult to study. Until recently, very few persons directly involved in the sex trade left first-hand accounts of their activities and motivations. Scientific analyses containing information about the social backgrounds and the working and living conditions of prostitutes in the past are usually based on sources (such as police records, judicial files, medical reports, data collected by relief institutions, newspapers clippings, and so on) that are inevitably incomplete and biased. What is more, in contrast to the analysis of other forms of work, it appears that the study of prostitution is also heavily influenced by emotions and personal views about female sexuality

37 Judith Walkowitz, "Jack the Ripper and the Myth of Male Violence", Feminist Studies, 8 (1982), pp. 542-574.

38 The term "white slavery" was used in the early 1800 s to denounce the plight of sailors of "white" nations captured by pirates in the North of Africa. Only by the end of the nineteenth century had the term become feminized and linked to the traffic of women for prostitution. In 1921, the League of Nations replaced the racialized term "white slavery" with "traffic in women and children".

39 This trend has not progressed in a linear way towards repression. Instead, waves of strong anti-trafficking and anti-prostitution campaigning can be discerned from the late $1800 \mathrm{~s}$ until the end of the 1930s and again since the last decades of the twentieth century. The last wave has run parallel to a movement that demands the recognition and redefinition of prostitution as sex work. 
and intimacy. ${ }^{40}$ Because sexuality evokes both empowerment and vulnerability, the bodily contact involved in prostitution can be seen as a reminder of women's capacity to adapt to harsh life circumstances, or as the quintessential symbol of female oppression. In both cases, the reputation of the trade is to a greater or lesser extent tarnished as the participants' consent is repeatedly put into question.

Many authors, policy makers, and activists argue that consent in prostitution is impossible or at least highly problematic. Inspired by radical feminism, some claim that prostitution is always coercive because no person can ever consent to rape. Women's consent to prostitution would simply be another sign of their "multi-layered oppression" and submission to male supremacy and violence. ${ }^{41}$ This is the logic behind the criminalization of purchasing sex, a move that was first made in Sweden at the end of the 199os followed by a few other countries in subsequent decades and passed by the European Parliament as a non-binding resolution in 2014. ${ }^{42}$ Others do not go as far as to equate prostitution with rape or sexual slavery but stress the gendered socioeconomic factors that push many women into prostitution. Even observers who treat prostitution as a form of work often specify that it is not a job like any other or create new concepts to draw a line of demarcation between sex work and other sexual-economic relationships. By doing so, they unwillingly reinforce the poor reputation of prostitution as well as the idea that real consent to this kind of unconventional occupation is unlikely. ${ }^{43}$

Since consent, agency, and coercion are dealt with in two separate chapters in this book, we wish here only to specify why the issue is so important to sex workers and highlight the argument that consent to sex work is no less possible than consent to other (substandard or stigmatized) jobs. As stated above, some

40 We are thankful to Jan Lucassen for bringing this point to our attention during the European Social Science History Conference, Vienna, April 2014. Hendrik Wagenaar and Sietske Altink, "Prostitution as Morality Politics or Why it is Exceedingly Difficult To Design and Sustain Effective Prostitution Policy", Sexuality Research and Social Policy, 9 (2012), pp. 279-292, argue that prostitution policy can be understood as an instance of morality politics. As such, much of prostitution policy is influenced by ideology, is emotionally charged, and is resistant to empirical evidence.

41 Jeffreys, The Idea of Prostitution, pp. 135-137.

42 "Punish the Client, Not the Prostitute", available at: http://www.europarl.europa.eu/news/ en/news-room/content/20140221IPR36644/html/Punish-the-client-not-the-prostitute; last accessed 7 July 2017 .

43 We would like to thank the members of the cost Action "Comparing European Prostitution Policies: Understanding Scales and Cultures of Governance" who raised this point during the second Action meeting, Salamanca, 10-13 September 2014. 
writers have argued that prostitution is so traumatizing that it is impossible to really consent to it, and that by consequence prostitution always lacks consent. Yet there is no lack of (past and contemporary) statements by women who insist that they work in the sex industry voluntarily. We do not deny that some women are forced to work in the sex trade. We also acknowledge that many women (and men) accept jobs under unfavourable circumstances, and only have unattractive options from which to choose. Many workers, both historically and today, have had to accept jobs which involved risks (including sexual harassment) or were unhealthy or demeaning. ${ }^{44}$ Hence we see no reason to treat sex work as a special case, unequal to all other kinds of work, ${ }^{45}$ or to disregard the voices of women who say that sex work was their choice among the options available to them. Acknowledgement of the existence of consent and agency in prostitution strengthens the view of prostitutes as workers and could facilitate the legalization of sex work and subsequent protection of the trade's employees. ${ }^{46}$

44 Economic constraints force millions of men and women into situations that are not necessarily of their liking and that are often harmfully exploitative. At its most abstract, all forms of labour can be described as coercive, as work implies a choice between two disagreeable alternatives and in extreme cases between two evils. According to Robert J. Steinfeld and Stanley L. Engerman, "Labor-Free or coerced? A Historical Reassessment of Differences and Similarities", in Tom Brass and Marcel van der Linden (eds), Free and Unfree Labour: The Debate Continues (Bern, 1997), pp. 107-126, no real distinction exists between free and slave labour in terms of a requirement to work in order to survive. In their view, the classification of labour into "free" or "unfree" is arbitrary. It is the law which determines "what kinds of coercive pressures are legitimate and illegitimate in labour relations."

45 As we write in the conclusion, we see prostitution as highly sexualized and highly gendered. In this characterization, it would perhaps be a better argument to treat sex work as a special category rather than dwell on the coercive, unhealthy and demeaning character of the occupation, but in our opinion treating sex work as incomparable with other kinds of work which often exhibit similar characteristics is not warranted either.

46 Barbara Sullivan, "Rethinking Prostitution and 'Consent", in F. Castles and J. Uhr (eds), Proceedings of the 2000 Conference of the Australasian Political Studies Association (Canberra, 2000), pp. 1-7, argues that for a long period sex workers have been unable to press charges when they were raped, as they were seen as always being available to men. In the countries she has researched (the United Kingdom, Australia, Canada, and New Zealand), this changed in the 1980 s and ' 90 . This new trend, as well as sex workers' increased involvement in public debates, are proof that the women concerned "negotiate consent within a particular set of power relations and are able to distinguish between their consensual work as prostitutes and non-consensual rape" (p. 3). If prostitution is seen as always involving rape, there is a risk that this change can become undone again. See also 
However, this has not convinced the advocates of the moral and oppression approaches to prostitution, who claim that women are either made to lie about their consent or have deluded themselves into believing that they do of their free will what they are really forced to do at home or abroad. Indeed, the issue of consent has been raised in relation to sex migration since the end of the nineteenth century. Even though the conflation of prostitution and "white slavery" was predominantly made in relation to underage white girls, ${ }^{47}$ the idea that no woman, regardless of her age, could consent to travel abroad and become engaged in prostitution became increasingly popular from the interwar period onward. During the 1920s, the League of Nations still made a differentiation between consenting adult women and underage children taken abroad for prostitution; the latter were always treated as victims of traffic, consent not being a defence. ${ }^{48}$ By the 1930 s, however, the League strengthened the argument that "even if a woman over age freely consents to being the object of the traffic, in the majority of cases she is not fully aware of the disaster to which she is being led." ${ }^{49}$ Subsequent conventions approved by the League and the United Nations made the consent of women irrelevant. ${ }^{50}$ In the year 2000, the United Nations approved the Protocol to Prevent, Suppress

Barbara Sullivan, "Rape, Prostitution and Consent", Australian and New Zealand Journal of Criminology, 40 (2007), pp. 127-142.

47 In 1910, the International Convention for the Suppression of White Slave Traffic was signed, and it included the offence of procuring adult women by means of fraud, violence, or other forms of compulsion, and women under the age of twenty even with their consent, for immoral purposes abroad.

48 In 1921, the International Convention for the Suppression of Traffic in Women and Children supplemented the provisions of earlier international agreements by extending the protection to women of twenty-one and to minors of either sex.

49 League of Nations Traffic in Women and Children Committee, Minutes of the Twelfth Session, Third Meeting, Geneva, 7 April 1933, p. 5, CTFE/12th Session/PV.3, League of Nations archives, United Nations Office at Geneva.

5o The 1933 International Convention for the Suppression of the Traffic in Women of Full Age covered the offence of procuring, enticing or leading away even with her consent, a woman or girl of full age for immoral purposes to be carried out in another country. In 1937, the League drafted a Convention for Suppressing Exploitation of the Prostitution of Others, intended to fill the gap in the existing conventions by protecting adults of either sex against procuration, even when they consented and were not taken abroad. The outbreak of World War II prevented its approval by the League's Assembly, but many of the main ideas included in the draft convention were taken up by the 1949 UN Convention for the Suppression of the Traffic in Persons and of the Exploitation of the Prostitution of Others. Magaly Rodríguez García, "The League of Nations and the Moral Recruitment of Women", International Review of Social History, 57 (2012), pp. 97-128. 
and Punish Trafficking in Persons Especially Women and Children, commonly known as the Palermo Protocol, and defined the crime of human trafficking as follows:

"Trafficking in persons" shall mean the recruitment, transportation, transfer, harbouring or receipt of persons, by means of the threat or use of force or other forms of coercion, of abduction, of fraud, of deception, of the abuse of power or of a position of vulnerability or of the giving or receiving of payments or benefits to achieve the consent of a person having control over another person, for the purpose of exploitation.

Article $3(b)$ of the Palermo Protocol specifies that the consent of a victim of trafficking is deemed irrelevant if any of the means cited above have been used. ${ }^{51}$ What was new about the Palermo Protocol was that it introduced a definition of trafficking in international law and that the issue of coercion and deceit are therein included. However, the definition is so broad that it can include cases in which the nature of coercion or control over another person is difficult to determine.

The problem with this broad understanding of trafficking and its blending with the migration of women who are in "a position of vulnerability" is that it reifies the mental binaries of victim/perpetrator without taking into account the fluidity and complexity of labour relationships in the sex trade (as well as in other economic activities). This approach easily negates the agency of migrant workers who often respond to push factors "rather than the pull factor of trafficker enticement."52 It also simplifies labour arrangements which often result in both progress and subjugation as well as improvements in workers' economic opportunities, and at the same time subjects them to exploitative working conditions. ${ }^{53}$

$5^{1} \quad$ Protocol to Prevent, Suppress and Punish Trafficking in Persons Especially Women and Children, supplementing the United Nations Convention against Transnational Organized Crime, available at: http://www.ohchr.org/EN/ProfessionalInterest/Pages/ProtocolTraffickingInPersons.aspx; last accessed 7 July 2017.

52 Ronald Weitzer, "New Directions in Research on Human Trafficking", The ANNALS of the American Academy of Political and Social Science, 653 (2014), pp. 6-24, 16.

53 Kimberley Kay Hoang and Rhacel Salazar Parreñas, "Introduction", in idem, Human Trafficking Reconsidered, pp. 1-18, 7-9. See also Lex Heerma van Voss, "The Worst Class of Workers: Migration, Labor Relations and Living Strategies of Prostitutes around 19oo", in Marcel van der Linden and Leo Lucassen (eds), Working on Labor: Essays in Honor of Jan Lucassen (Leiden [etc.], 2012), pp. 153-170. 
Human trafficking is therefore an ambiguous notion that requires further empirical research ${ }^{54}$ and that has, in our view, no linear relation with prostitution. Just like issues of concepts, policies, race, ethnicity, class, health, violence, space, the role of war, and male concentrations in industrial, military, and administrative hubs, forced (migration for) prostitution is a theme that appears in all the contributions to this book but receives no special treatment in a separate comparative chapter.

The volume is divided into two parts, one containing twenty-three urban overviews while the other includes eight thematic papers. All the authors of the urban essays were required to cover prostitution in the city or town in question between 1600 and the present, or for the time it existed if the city did not exist as a town of sufficient size for the full four centuries. As stated above, the authors were instructed to follow a framework document and to answer a set of questions on three broad themes. This explains the (relative) homogeneity of all the urban overviews. Since we were interested in how the history of sex work has been approached in different times and places, as well as in the various legal and cultural definitions used by state and non-state actors in each city, one section of each paper is devoted to historical contextualization, historiography, and definitions. A second theme is related to societal reactions regarding prostitution. Society is here broadly conceptualized and refers to the way that public authorities and private actors have responded to prostitution across time and space. Local, national, and international initiatives to control, regulate, and/or repress the sex trade, as well as the role played by religious and secular organizations in "redeeming" prostitutes or defending their interests, are included in the analyses. The third theme concerns the labour market for prostitution, more precisely the prostitutes' social profiles; political and socioeconomic factors influencing the sex trade (urbanization, industrialization, colonization, war, demographic transitions, and revolutions in communications and transport); changes in working conditions (indoor or outdoor prostitution, payment systems, prostitution as a part- or full-time activity, relations to other forms of "female occupations", and so on); the prostitute/employer/clientrelationship; and sex workers' culture (hierarchy, solidarity, organization, selfrepresentation, and views on prostitution). The urban overviews are organized

54 On the difficulties of measuring the phenomenon and on the absence of the opinions of sex-work migrants in narratives of human trafficking, see: Paul Knepper, "Measuring the Threat of Global Crime. Insights from Research by the League of Nations into the Traffic in Women", Criminology, 50 (2012), pp. 777-809; Brenda Oude Breuil et al., "Human Trafficking Revisited: Legal Enforcement and Ethnographic Narratives on Sex Trafficking to Western Europe", Trends in Organized Crime, 14 (2011), pp. 30-46. 
in four regional sections: Europe, Africa and the Middle East, the Americas, and Asia-Pacific.

The willingness of the authors to respond to (most of) these issues facilitated the preparation of comparative papers on prostitution in relation to labour relations, working conditions, migration, colonization, agency, coercion, gender, and social profiles. Hence the thematic overviews are based on the results of the different urban papers but the authors were given the liberty to use the available literature and approaches they deemed necessary to discuss the theme under consideration. Inevitably, there is some overlap in the various themes, but we do not consider this to be a problem. On the contrary, the interrelation between various issues - for example, migration and working conditions or gender and colonization-adds to a better understanding of the complexity of prostitution.

The intricacy of the subject, combined with the almost complete lack of information for many periods, places, and actors, results in a global history that does not cover each corner of the globe or each period to the same degree. We have covered every region of the world, but sub-Saharan Africa is underrepresented. Information about many ex-colonies in the Americas, Africa, and Asia for the period before the nineteenth century, as well as on prostitution in rural or suburban areas is often unavailable. Similarly, historical data about male and underage prostitutes or on clients and third parties is even more scarce than material on female sex workers. Yet, as is demonstrated in the concluding chapter, the cities and themes included in this volume provide a solid basis for a global history of prostitution and we are confident that they also make a valuable contribution to a more comprehensive understanding of the world of labour. 


\section{Appendix 1: Framework Document for Urban Overviews}

1. Introduction: A few paragraphs historiography, methodology and sources

2. Definitions: overlapping of legal and cultural definitions throughout place and time: This section should make clear what in the town (country, culture) discussed a prostitute was considered to be; what activities constituted (also) prostitution (e.g. adultery and which did not (e.g. sexual services from a slave to her master); which sexual services were considered close to or distinct from prostitution?

\section{The labour market for prostitution:}

\section{Push and pull factors}

Urbanization and industrialization

Proletarization and pauperization

Gender segregation in the "regular" labour market

Demographic transition (delayed marriages and family formation)

Concentrations of males with money to spend: mines, garrison towns, naval bases, ports ...

War

Migration

Women's economic emancipation: decline of prostitution? (possible to measure?)

Communication and transport revolutions and their influence on prostitution

Changes of working conditions throughout time and place

Indoor, outdoor soliciting

Payment systems (exchange of sex for any valued commodity/sexual barter: also considered prostitution?)

Independent work or under protection of madams, pimps or escort agents?

Prostitution during wartime and near military concentrations in times of peace

Prostitution as casual or permanent employment: part- or full-time activity?

Relation to other forms of sex work (dancing, stripping, massage) or related professions (masseuse, nightclub hostess)

\section{Prostitutes' social profiles}

Religious, racial and ethnic backgrounds

Education level

Employment prior or parallel to prostitution

Family situation (married; unmarried; children ...)

Age structure (age of beginning and end of prostitution): temporary or life-long activity? 


\section{Prostitute/employer/client-relationship}

Conditions of compliance and traces of defiance (formal and informal activism) towards clients, employers and/or labour intermediaries (pimps, madams, brothel keepers, escort agents, owners of massage parlours or barber shops ...)

Material conditions of subservience imbedded in a wider structure of gendered, economic, class or racial subservience?

\section{Prostitutes' culture}

Hierarchy

Did issues of race, ethnicity and class play a role in the shaping of hierarchy? And vice versa: did prostitution help produce racial and class hierarchies?

How did location, types of clients, levels of protection (madams, pimps, escort agents, etc.) and earnings influence the shaping of hierarchies?

Solidarity: Did social constructs based on race, religion, class and age encourage or discourage group solidarity?

Self-presentation and prostitutes' attitudes towards prostitution: survival, inclination, emancipation, desire for luxury consumption, attraction to easy earnings, disdain of "normal" work ...?

\section{Society and prostitutes:}

State and non-state persecution and violence

State regulation/prohibition/tolerance

Prostitutes' physical and psychological health

Non-state actors' activism: religious and secular social workers; feminists

Effects of women liberalization (tolerance of pre-marital sex): decline of prostitution? Increased acceptance of prostitution as a way of life?

\section{5. (Optional) Special cases:}

Child prostitution

Male and homosexual prostitution

Prostitution in non-urban areas 